Håvard Skaar

Høgskolen i Oslo og Akershus

Lisbeth Elvebakk

Høgskolen i Oslo og Akershus

Jannike Hegdal Nilssen

Høgskolen i Oslo og Akershus

\title{
Lærerstudenten som frafallen leser - Om litteraturens fremtid i norsk skole
}

\begin{abstract}
Young people's reading of literature is in decline in Norway, and research shows that teacher students read less than average. To be able to address this problem adequately we investigated why teacher students read as little as they do. In a qualitative investigation informed by phenomenological hermeneutics, we got permission to analyze the assignment "My reading history" which was handed in by 163 teacher students. The reasons the students gave for reading, or not reading, suggest that at present literature reading is under pressure both within and outside teacher education institutions. A majority conveyed a high valuation of literature together with a description of no or very little reading in their personal lives. We interpret this divergence in light of the participants' role as teacher students and the situation in which the students wrote their reading histories. These circumstances are judged to neither explain nor weaken the strong tendency among the students to evade or not prioritize reading of literature in their daily life. In addition, their explanations for lack in reading engagement make it difficult to assume they will become more eager readers in the future. Thus, the study implies that the mother tongue subject in teacher education have an incresingly difficult task if the ambition is to compensate for all the reasons given by these students for opting out of reading literature. It seems less likely than before that students will be able to draw on a personal interest in literature as future teachers.
\end{abstract}

Key words: phenomenological hermeneutics, engagement in reading, teacher students, literature reading

\section{Sammendrag}

På nasjonalt nivå er unge menneskers lesning av skjønnlitteratur synkende, og lererstudenter er blant dem som leser minst. Hvordan skal lererutdanningene forholde seg til dette? Svaret på spørsmålet forutsetter mer kunnskap om 
hvorfor larerstudenter leser så lite som de gjør. Derfor samlet vi inn 163 lererstudenters beskrivelser av seg selv som lesere. Analysen av studentenes fortellinger om egen lesing ble teoretisk og metodisk forankret i hermeneutisk fenomenologi. De momentene studentene trakk fram som årsakene til at de leser eller lar væere, tyder på at lesing av skjønnlitteratur i dag er under press både $i$ og utenfor lererutdanningene. For et stort flertall av studentene stod en entydig oppvurdering av skjønnlitteraturen i motsetning til en svcrt begrenset personlig befatning med lesing av skjønnlitteratur. I fortolkningen av denne motsetningen tar vi i betraktning studentenes rolle som lererstudenter og den situasjonen de befant seg i da de fortalte sin historie. Ingen av delene blir ansett å svekke den klare tendensen til at lesing blir nedprioritert eller valgt bort i disse studentenes dagligliv. Studentenes begrunnelser for egen leseinteresse gir også liten støtte for at de vil lese mer i fremtiden. Undersøkelsen peker i retning av at norskfaget i lererutdanningsinstitusjonene har et stadig mer krevende oppdrag, dersom ambisjonen er å kompensere for alle de grunnene disse studentene gir for å la vere å lese skjønnlitteratur. Det synes mindre sannsynlig enn for at lcererstudenter vil kunne trekke på en personlig interesse for lesing i sin fremtidige larerrolle.

Nøkkelord: hermeneutisk fenomenologi, leseinteresse, læererstudenter, skjønnlitteratur

\section{Innledning}

Skjønnlitteratur har fremdeles en sentral plass i skolens norskfag, men etter revisjonen i 2006 ble titler og forfatternavn tatt ut av den nasjonale læreplanen. Det betyr at lærerne i større grad enn før selv kan velge litteraturen de vil bruke i klasserommet. I vurderingen skal de ta hensyn både til elevenes leseferdighet, interesser og deres krav på tilpasset opplæring. Læreplanens forutsetning er altså at lærerne bruker sitt eget faglige skjønn og sin egen fagkunnskap til å tilby best mulig litteraturundervisning til elevene.

Samtidig viser forskning både at mange lærerstudenter leser lite, og at en betydelig andel ikke leser i det hele tatt (Brink, 2009; Wicklund, Larsen \& Vikbrant, 2016). Lærerstudenter som utdanner seg for barnetrinnet er de som leser aller minst (Petersson, 2009). Disse undersøkelsene er utført av forskere som er direkte involvert i utdanningen av lærerstudenter. Som lærerutdannere er vårt oppdrag å hjelpe studentene til å utvikle sin litterære kunnskap og forståelse. Da trenger vi mer kunnskap om hvorfor lærerstudenter leser så lite som de gjør.

Denne artikkelen er basert på hva 163 lærerstudenter på barnetrinnet har å fortelle om dette. I lesehistorier på én til to sider beskrev de hvordan lesingen 
deres hadde utviklet seg gjennom livsløpet, og gav samtidig sine egne fortolkinger av, eller forklaringer på, det som hadde skjedd med lesingen deres.

Den generelle tendensen er at lesingen deres svekkes fra ungdommen og frem til voksen alder. Noen gir opp helt, mens en betydelig andel har endt opp med å lese svært lite. For å finne ut hva som kan være årsakene til dette, har vi undersøkt sammenhengen mellom følgende tre spørsmål:

1. Hva forteller studentene at de har lest?

2. Hvordan har lesingen deres utviklet seg gjennom livsløpet?

3. Hvordan forklarer studentene sitt forhold til å lese skjønnlitteratur?

Etter å ha redegjort for eksisterende forskning, klargjør vi vårt teoretiske og metodiske utgangspunkt for å fortolke det studentene fortalte om sin egen lesing. I den første delen analyserer vi opptellingen av hva studentene har lest. I den neste delen ser vi på hvordan fortellingene deres er strukturert, og hvilke typiske motsetningsforhold som kommer til syne i dem. I siste del diskuterer vi hva undersøkelsen forteller om hvilken rolle lærerutdanningene vil kunne spille for nåværende og fremtidige studenters utvikling som lesere.

\section{Eksisterende forsking}

Statistisk sentralbyrå rapporterer at 25 prosent av befolkningen var boklesere i 2014. Andelen var den samme for 25 år siden. I aldersgruppen 16-24 år har andelen i samme periode sunket (fra 28 til 18 prosent), mens den i aldersgruppen 25-44 år har holdt seg stabilt like under gjennomsnittet for hele befolkningen. Boklesing blir definert som lesing av trykte bøker, høytlesing for barn og lesing i forbindelse med yrke og utdanning er ikke medregnet. Skjønnlitteratur ble mest lest (Vaage, 2015, s. 31-32). I den nasjonale ungdomsundersøkelsen for 2014 viser boklesing (ikke skolebøker) blant ungdom en svakt synkende trend de siste fem år (NOVA, 2015, s. 56). Leserundersøkelsen 2014 rapporterer også om at lesing av bøker (papirbøker, lydbøker og e-bøker, ikke skolebøker og annen pensumlitteratur) i befolkningen som helhet holder seg stabilt, samtidig som det her er en markert nedadgående trend for aldersgruppen 15-24 år. Tendensen er den samme for aldersgruppen 25-39, men ikke like sterk (DNF, 2014). Den eldre del av befolkningen leser derimot mer enn før. For øvrig viser alle disse undersøkelsene at internettbruk øker kraftig, spesielt blant yngre mennesker. Når det gjelder høytlesing for egne barn viser en britisk studie at et synkende antall fedre engasjerer seg i dette (Clark \& Picton, 2012). Den samme studien fremholder, i likhet med norske undersøkelser (se for eksempel Bergersen, 2015), hjemmets sentrale betydning for barns utvikling av leselyst.

Når skjønnlitteraturens plass i skolen blir undersøkt, er det ofte læreplanens ordlyd, litteraturdidaktisk teori og praksis eller elevens perspektiv som er 
utgangspunktet (se for eksempel Dokset, 2015; Hamre, 2014; Kaspersen, 2012; Kjelen, 2013; Penne, 2012). To bidrag tar opp norske lærerstudenters litteraturkunnskap og forståelse, basert på studenttekster og besvarelser på litterære oppgaver til eksamen (Kjelen, 2014; Skaftun, Karlsen \& Syversen, 2015). En masteroppgave tallfester lesingen til lærere i videregående skole (Storrusten, 2010). For grunnskolenivået finnes det en undersøkelse av norske og svenske lærerstudenters lesing, mens det finnes flere svenske undersøkelser av tilsvarende (Petersson, 2009; Thorson, 2009). Foruten lesing av litteratur har sammenhengen mellom grunnskolelæreres litterære valg i klasserommet og deres egne lesepreferanser blitt undersøkt (Brink, 2009).

Den ovennevnte nedgang i skjønnlitterær lesing blant unge (Vaage, 2015; NOVA, 2015; DNF, 2014) er også påvist i Sverige (Johnsson, Smaragdi \& Jönsson, 2006). Det er tilsvarende en påfallende beskjeden leseinteresse som kommer til uttrykk i både svenske og norske undersøkelser av barnetrinnlæreres lesing (Jönsson \& Eriksson, 2003; Petersson, 2009; Wicklund et al., 2016).

Det finnes også amerikanske studier av lærerstudenter og læreres lesevaner og litterære interesser. Både Nathanson, Pruslow og Levitt (2008) og Applegate og Applegate (2004) fant at interessen for å lese litteratur ikke var sterk blant lærerstudenter. McKool og Gespass (2009) fant at selv om lærere verdsatte lesing av litteratur, var tiden de brukte på lesing ganske begrenset. De fant også at de lærerne som satte størst pris på litteratur, hadde størst evne til å inspirere sine elever til lesing. Kennedy (2014) fant at lærerstudentene i hennes studie ikke var engasjert i lystlesing (pleasure reading). De fleste manglet interesse for å lese, selv om de rapporterte om positive barndomsopplevelser knyttet til lesing.

\section{Materiale, teori og metode}

Undersøkelsen er basert på lesehistoriene til 163 studenter på en større norsk lærerutdanningsinstitusjon. Lesehistoriene var et obligatorisk arbeidskrav som ble samlet inn i 2015. Oppgaveteksten lød slik:

Min lesehistorie: Hvem leste for meg da jeg var liten, hva husker jeg best? Bøker eller tegneserier jeg var spesielt glad i og hvorfor. Bøker vi leste på skolen som høytlesing. Bøker jeg lånte på skolebibliotek eller annet sted, hva jeg syntes om dem. Hva jeg leste på fritida opp gjennom årene. Hvilket forhold har jeg til lesing i dag, hva slags leser er jeg?

Det teoretiske utgangspunktet for å analysere lesehistoriene er fenomenologisk hermeneutikk (Gadamer, 1975/1996; Husserl, 1913/1983). Husserl avviste dikotomien mellom det subjektive og objektive ettersom enhver erkjennelse nødvendigvis er subjektiv, dermed også erkjennelsen av skillet mellom subjekt og objekt. Med sin fenomenologiske metode ville han avdekke hvordan noe, for 
eksempel lesingen av skjønnlitteratur, fremstår og får mening for oss i det han kalte vår livsverden. Gjennom å forholde seg metodisk stringent til analysens subjektive forutsetninger, ønsket han å bestemme både tingenes essens og betingelsene for vår egen opplevelse av dem. For Gadamer er det den fenomenologiske fortolkningsakten som står i fokus. Spørsmålet er ikke hva som er fenomenets essens, men heller hvilket rom for fortolkning det gir oss. For ham innebærer subjektiviteten et sett med fordommer som gjør fortolkning mulig. Fordommene, eller de subjektive betingelsene for å forstå livsverdenen, er fortolkningens forutsetninger. Samtidig medfører fortolkningen av et fenomen at våre fordommer endres, og Gadamer teoretiserer denne dynamikken. Det er denne typen hermeneutisk fortolkning av fenomenet skjønnlitterær lesing vi gjør i denne undersøkelsen. Metodisk er vår framgangsmåte i stor grad i samsvar med det som kalles fenomenologi innenfor den nordamerikanske tradisjonen for kvalitativ forsking (Schwandt, 2015).

På pensum for studentene i vår undersøkelse er det lagt opp et antall barnebøker og bildebøker, og oppgaven de fikk ble gitt etter et fire uker langt undervisningsopplegg med barnelitteratur som tema. Studentene leverte altså inn sin lesehistorie etter å ha blitt eksponert for et pensum, en undervisning og for faglærere som understreket at barns lesing av skjønnlitteratur er viktig og verdifullt. Studentene fikk dermed formidlet en slags lærerutdanningens "idealiserte leser" av de samme faglærere som skulle godkjenne lesehistoriene deres som arbeidskrav. Det vil si at vi kan gå ut fra at våre fordommer, i gadammersk forstand, virket dobbelt. Først på det studentene valgte å fortelle, og deretter på hvordan vi valgte å fortolke det. Vi har ikke sett bort fra dette, men heller prøvd å identifisere hvilke motsetninger som kommer til syne når våre fordommer, både som lærerutdannere og fortolkere av lesehistoriene, blir holdt opp mot det studentene fortalte.

Med et stort antall historier hadde vi en metodisk begrensning i forhold til i hvilken grad vi kunne gi detaljerte redegjørelser for den enkelte histories særpreg. Derfor valgte vi å legge mest vekt på de typiske trekkene vi fant. Lesehistorien var en fritt disponert tekst, og vi kartla først studentenes lesing ved å telle opp referansene de gav til navn på serier (for eksempel Harry Potter eller Narnia), litterære titler og forfatternavn. Disse spesifikke referansene gav oss en indikasjon på hvilke bøker studentene har lest. Når et verk, en serie eller et forfatternavn ble nevnt spesifikt, anså vi det som sannsynlig at studentene faktisk hadde lest boka eller bøkene. Vi lot hver referanse til verk, forfatter eller serie telle ett poeng, og talte opp poengene.

Det er en svakhet ved denne fremgangsmåten at vi ikke kan være sikre på samsvaret mellom antallet nevnte titler i historiene og studentenes interesse for å lese. Det er altså ikke mulig å se bort fra at en student kan ha lest mange bøker uten å nevne titler eller forfatternavn. Vi regnet likevel med at de sterke normative føringene som lå til grunn for oppgaven heller ville få studentene til å overdrive enn underdrive sin interesse for lesing av skjønnlitteratur. Titler og 
navn ble derfor fortolket som et uttrykk for en troverdig fremstilling av egen lesing, og som opplysninger det ikke var rimelig å anta at studentene generelt sett ville holde tilbake når de skulle skrive lesehistoriene sine.

Vi hadde først flere møter der vi undersøkte avvik i referansene hver av oss hadde funnet i fem av historiene. Det fikk oss til å justere noen av kategoriene før vi fordelte lesehistoriene mellom oss, og talte opp referansene i alle de 163 historiene. 20 historier ble talt opp dobbelt. Det fremkom da et avvik i kategoriseringen av de litterære titlene på 7 prosent. På bakgrunn av dette ble referansene i alle historiene talt opp av minst to forskere for å kvalitetssikre tallene.

Deretter gikk vi over til en analyse av studentenes beskrivelser av sitt eget forhold til lesing, og deres utvikling som lesere. Med lesing mener vi både lesing av skjønnlitteratur ut av egen interesse, og lesing av skjønnlitteratur som har blitt pålagt i skolesammenheng. De fleste gav en beskrivelse fra så langt tilbake som de kunne huske, og frem til tidspunktet da de skrev sine lesehistorier.

To kriterier måtte være oppfylt for at vi skulle vurdere studentenes forhold til lesing av skjønnlitteratur som positivt. For det første måtte de fortelle at lesing (eller å bli lest for) faktisk hadde funnet sted, og for det andre måtte de beskrive denne lesingen som en positiv opplevelse. For å kartlegge utvikling av lesingen gjennom livsløpet, undersøkte vi hvorvidt disse to kriteriene var oppfylt i barndommen, ungdomstiden og voksenlivet.

På samme måte som da vi talte opp titler og forfatternavn, hadde vi innledningsvis to runder der vi sammenlignet analysene som hver av oss hadde gjort av fem tilfeldig utvalgte studenters historier. Avvik mellom våre vurderinger i begge disse rundene fikk oss til å spesifisere kriteriene for “positivt” eller "negativt forhold til lesning”, før to av oss gikk videre med å sammenligne hvordan vi hver for oss hadde vurdert 40 av historiene. I denne runden var det langt mindre avvik, kun for tre historier. Etter denne siste sammenligningen talte en av oss opp fordelingen i resten av materialet. Det skal bemerkes at selv når vi sammenlignet resultatene gjorde den åpne formen det noen ganger vanskelig å bestemme om studentens forhold til lesing var positivt eller negativt. Slike tilfeller har vi ikke talt som "positivt forhold til lesing”, men kategorisert som "umarkert".

På denne måten fikk vi kunnskap om fenomenet på en måte som, selv om tallene ikke er statistisk holdbare, gav oss et numerisk grunnlag for å sammenligne studentenes lesing (Maxwell, 2009). Det høye antallet historier gjør det også mulig å undersøke sammenfall og variasjoner i det studentene beskriver. Det kan fortelle noe om hvilke opplevelser av fenomenet studentene deler, og om hva som kjennetegner den enkelte students unike opplevelse.

I fortolkningen av historiene lette vi etter konflikter og motsigelser i utviklingen av den leseropplevelsen som studentene beskrev (Langdridge, 2008). Vi gikk for eksempel ut fra at det å skulle skrive lesehistoriene ville 
kunne få frem konflikter mellom studentenes faktiske forhold til lesing, og den oppvurderingen av skjønnlitteratur som de nettopp hadde møtt i studiet. Vi ønsket å identifisere slike fordommer for å finne ut mer om forholdet mellom hva slags type lesere studentene er, hva slags type lesere de gjerne skulle vært, og hva slags type lesere de ser for seg at de kan bli i framtiden.

\section{Funn}

\section{Hva studentene hadde lest}

Hver referanse til verk, forfatter eller serie talte altså ett poeng, da poengene ble summert fikk hver av studentene en poengsum. Gjennomsnittlig poengsum for referanser i lesehistoriene til verk, serie eller forfatter var 10, mens den mest typiske poengsummen (typetallet) per kategori litteratur var 0, se Figur 1 og Tillegg A og B.

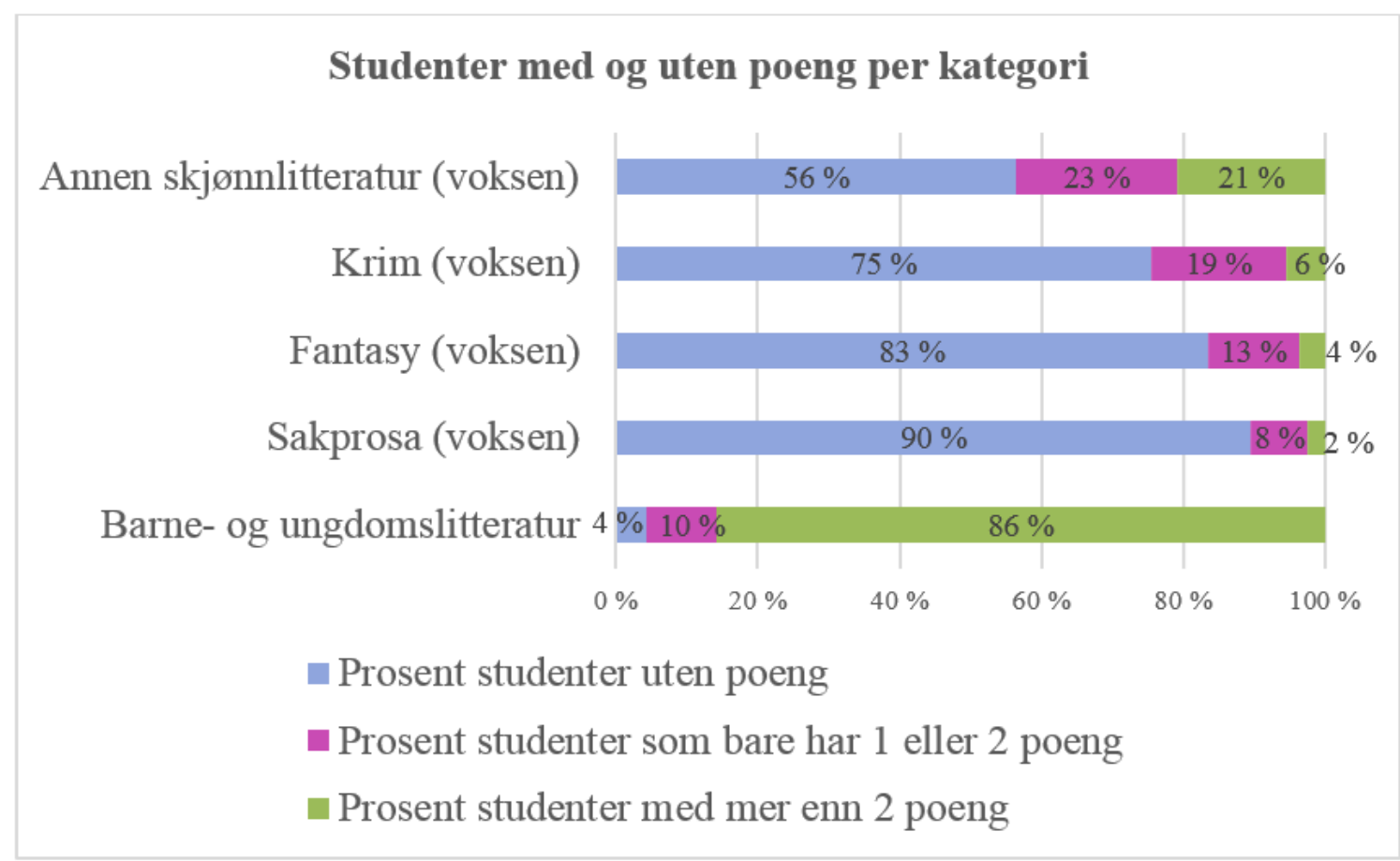

Figur 1: Prosentvis fordeling av studenter med og uten poeng per kategori litteratur

Vi må ta forbehold om at det ikke nødvendigvis er slik at man nevner forfattere og titler i en historie om egen lesing. Det går selvfølgelig an å være en ivrig leser uten å være spesifikk i forhold til litterære preferanser. Når tallene blir sett i sammenheng med deltakernes svar på spørsmålene til slutt i oppgaven de fikk (“Hvilket forhold har jeg til lesing i dag, hva slags leser er jeg?”), ser vi imidlertid et sammenfall mellom få titler og forfatternavn, og liten eller ingen interesse for å lese litteratur. Vi fant også samsvar mellom de litterære 
preferansene som blir uttrykt i form av sjangerhenvisninger, og referansene til titler og forfatternavn. En interesse for fantasy blir for eksempel supplert med henvisninger til Harry Potter og Ringenes Herre.

Figur 2 viser at krim og fantasy skiller seg ut som store enkeltsjangre (til sammen 9 prosent), mens sakprosa utgjør 2 prosent. I kategorien annen skjønnlitteratur har vi plassert all øvrig litteratur (både oversatte bestselgere og kanonisert norsk litteratur). Denne samlekategorien blir med 12 prosent av titlene så vidt større enn de tre andre til sammen.

Figur 2 viser også forholdet mellom oppgitte titler for barnelitteratur og voksenlitteratur. Den relativt store mengden referanser til barnelitteratur kan skyldes at studentene nettopp har vært igjennom et opplegg med barne- og ungdomslitteratur der barnelitterære titler er en del av pensum, samt at oppgaveformuleringen tematiserer barnelitteratur i større grad enn voksenlitteratur. Samtidig peker studentenes fremstilling av utviklingen av egen lesing gjennom livet på en generell tendens til å sette mindre pris på lesing i voksen alder enn i barne- og ungdomstiden.

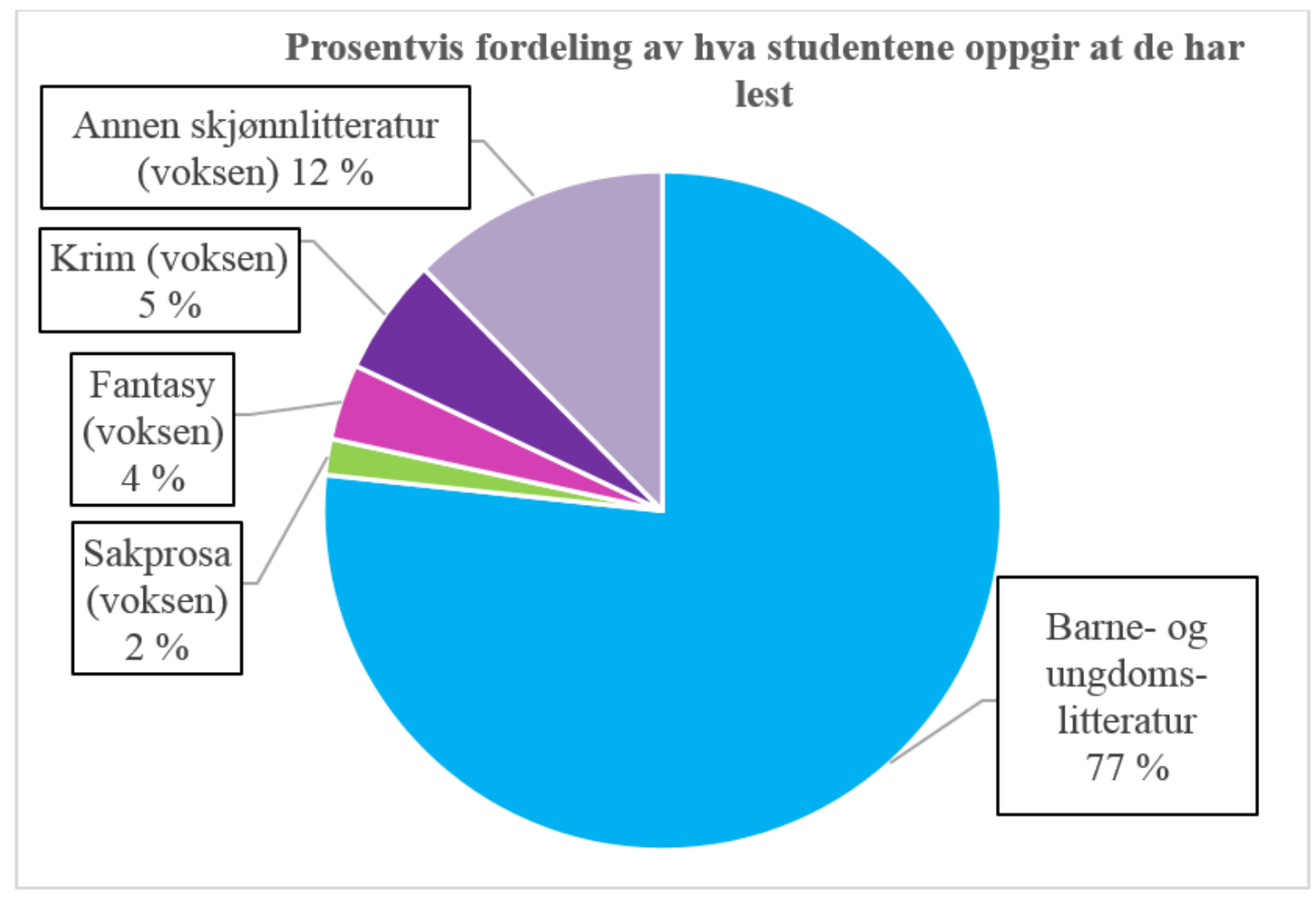

Figur 2: Prosentvis fordeling av titler og forfatternavn som er nevnt i studentenes historier

\section{Studentenes utvikling som lesere}

Studentenes lesing har hatt fire typiske forløp gjennom livet (se Figur 3 og tillegg C). Flertallet (103 av 163) beskriver et positivt forhold til litteratur som har blitt opprettholdt gjennom ungdommen og inn i voksenlivet. I denne gruppa 
er det imidlertid bare halvparten (50 av de totalt 103) som faktisk oppgir titler eller forfatternavn for voksenlitteratur.

En mindre gruppe (31 av 163) forteller at de ikke har beholdt den positive opplevelsen av lesing fra barndommen gjennom sin ungdom og/eller sitt voksenliv. I stedet har lesingen blitt forlatt til fordel for andre aktiviteter.

For en liten gruppe (11 av 163) har utviklingen gått i motsatt retning. På tross av at de ikke har vært lesere i barndommen, har de altså utviklet et positivt forhold til lesing i ungdommen eller i voksen alder. Det finnes også en mindre gruppe (18 av 163) som forteller at de ikke hatt et positivt forhold til lesning i noen livsfase.

I det følgende vil vi gå nærmere inn på hvorfor studentene leser eller ikke leser, og hvorfor de synes at de burde lese mer.

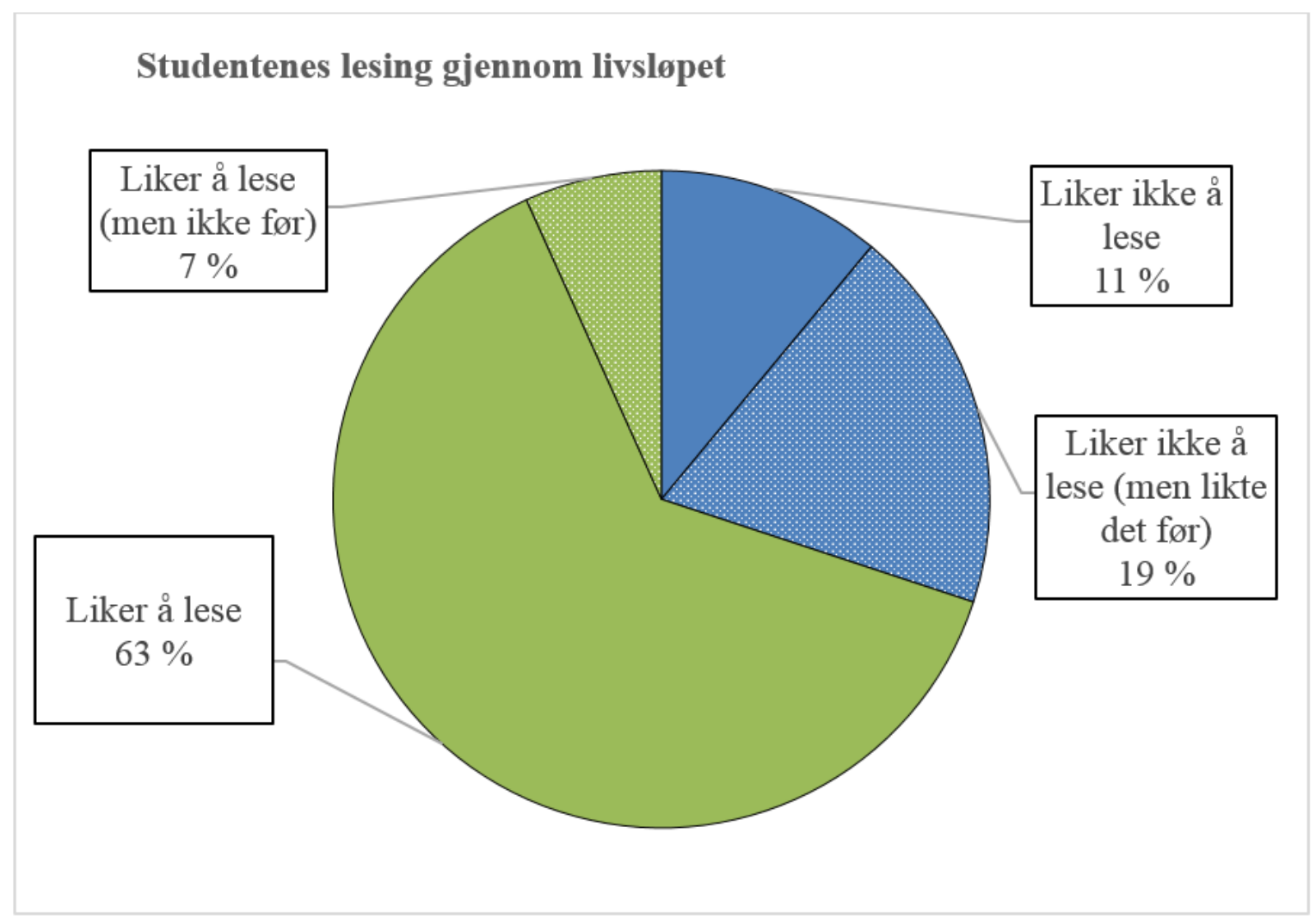

Figur 3: Studentenes lesing gjennom livsløpet (Se også tillegg C)

\section{Hvorfor studentene ikke leser}

Blant studenter som alltid har satt pris på lesing av skjønnlitteratur (103 av 163), blir det tatt flere forbehold når det gjelder lesing i ungdomstiden og voksenlivet, enn i barndommen. Lesingen har ikke stoppet opp, men et stort flertall i denne gruppen (72 av 103) forteller at den har fått liten plass og betydning i deres hverdag. De gir først og fremst tre forklaringer på at de ikke leser så mye som de gjerne skulle ønske. To tredeler (44 av 72) forklarer dette med at de ikke har tid til å lese lenger. Det som tar tiden deres er lesing av pensumlitteratur, jobb og 
andre forpliktelser. 16 av 72 forteller at det er et ork å sette seg ned med en bok etter at andre gjøremål er unnagjort. De opplever at det er lettere å ty til internett, aviser og tv. 12 av 72 forklarer manglende lesing med at de ikke finner gode nok bøker.

Studentene i gruppen der utviklingen har gått fra et positivt til negativt forhold til lesing (31 av 163) oppgir først og fremst manglende interesse og konsentrasjon som årsaker. 23 av de 31 studentene forteller at de ikke lenger synes litteratur er interessant. De finner i liten grad bøker som er gode nok til at de ønsker å bruke tid på lesingen, og derfor er de blitt mer interesserte i andre aktiviteter og hobbyer. Noen forteller også at de rett og slett ikke setter pris på å lese lenger:

Jeg trodde at Harry Potter bøkene kunne vært en døråpner for meg til andre bøker, men jeg klarte aldri å sette meg inn i noe på samme måte siden, og har lest særdeles få bøker siden Harry Potter bøkene. Kanskje var det en nedtur å lese annen litteratur etter å ha vært så oppslukt av det magiske universet.

Samtidig blir mangel på konsentrasjon og fravær av spenning også oppgitt som årsaker:

Stadig vekk tar jeg opp en bok for å sette meg ned å kose meg. Det ender nesten alltid med at jeg leser i 20 minutter, blir litt ukonsentrert, og gjør noe annet. Jeg kommer til å prøve å bli hekta på lesing helt til jeg klarer det, eventuelt ikke klarer det.

Noen forteller at de mangler både interesse og konsentrasjon. Studentene i denne gruppen tenker seg likevel at skjønnlitteraturen kunne tilført dem noe positivt, som de beklageligvis går glipp av.

I den relativt lille gruppen som har beveget seg fra et negativt til et positivt forhold til lesing (11 av 163), har fire en flerkulturell bakgrunn. De forteller at foreldrene deres ikke leste for dem da de var barn, og at de på grunn av sin språklige bakgrunn har måttet gjøre store anstrengelser for å kunne holde tritt med klassekameratenes leseutvikling. Da de var yngre var lesingen for vanskelig til at de kunne glede seg over den. I ungdomstiden, eller i voksen alder, har problemene likevel blitt overvunnet. Dermed beskriver de en forsinket, men positiv, opplevelse av litteratur:

Min mor og fars norskkompetanse ikke var god den tiden da jeg var liten. [...] Min kjærlighet for litteratur ga ikke gnist før på begynnelsen av 20-årene. Jeg begynte å lese med utgangspunkt til en oppgave på videregående. Men det stoppet ikke der.

For en annen gruppe i denne kategorien er det ikke den flerkulturelle bakgrunnen som har gjort lesing til en negativ eller fraværende opplevelse i barndommen. Årsaken har vært generelle lese- og skriveproblemer og/eller 
mangel på konsentrasjon. Når disse problemene senere blir overvunnet, oppdager disse studentene litteraturen på nytt:

Eg har alltid følt meg som ein treig lesar også, det å lese høgt i klassa var noko av det verste eg visste. Heilt forferdelig flaut. Eg målte meg alltid opp mot dei beste og meinte at eg burde vere der eg òg. Slik er det nok også den dag i dag til ei viss grad, noko som er litt leit og kan fort ta motet frå ein. Heldigvis har lesevanane mine endra seg med åra og eg føler at eg har blitt ein betre lesar, samt å ta inn det eg les. Sjølv om det var lite lese-stimuli i heimen, har eg i seinare tid fått ei større leseglede, noko eg er veldig glad for.

Studentene i gruppen som aldri har interessert seg for å lese litteratur (18 av 163), tror heller ikke at en slik interesse vil dukke opp i fremtiden. 12 av studentene i denne gruppen forteller at de ikke finner noen glede i å lese. De forteller at de ikke var interesserte i bli lest for som barn, og heller ikke nå greier å la seg "oppsluke” av litteratur. 9 av studentene i gruppen oppgir at årsaken til at de ikke liker å lese er at det er for krevende. De karakteriserer seg selv som svake lesere, og mener at de ikke har greid å overkomme vanskene. Flere forteller også at opplevelsen av å bli "tvunget” til å lese, både på skolen og hjemme, har ført til et negativt forhold til lesing som de ikke tror de kan endre på.

Generelt ser studentene ut til å dele en opplevelse av at lesing er en svært krevende aktivitet. Problemene oppstår når de ikke opplever å bli oppslukt på en måte som får dem til å synke inn i en vedvarende og fullstendig leseopplevelse. På forhånd har de håp om å bli revet med, men når de prøver å sette seg "ned i en god stol med en bok" opplever de at de blir rastløse, og ikke har den roen som er nødvendig for å lese. Noen uttrykker at de ikke opplever at litteraturen skaper "ro og fred" eller lar dem "stresse ned". Lesingen kan ikke "fange dem" og holde dem fast i spenning eller "drøm”. Dermed blir lesingen en skuffelse, og studentene gir opp etter noen få sider. En gjennomgående erfaring er at hvis boken ikke "er spannande i starten kjem eg ikkje til å lese han ferdig”. Andre ting "frister mer”.

\section{Hvorfor studentene leser}

Noen studenter spesifiserer ikke hvorfor de liker å lese litteratur, andre gir konkrete beskrivelser av hva de setter pris på. Vår opptelling viser hvilke årsaker som blir nevnt mest hyppig. Samtidig er begrunnelsene for lesing sammensatte, slik at mange studenter nevner flere grunner samtidig. 31 av 163 forteller at lesingen skaper en opplevelse av kos og hygge, mens 30 av 163 oppgir spenning som drivkraft. 23 av 163 vektlegger at lesningen er nyttig, lærerik eller gir innsikt. I denne kunnskapsutviklingen står styrkede språklige ferdigheter sentralt.

Noen studenter forteller at lesingen er avgrenset til en bestemt person eller et bestemt fenomen. De leser altså ikke skjønnlitteratur i tradisjonell forstand, men 
dokumentariske eller biografiske fremstillinger med større eller mindre innslag av skjønnlitterære elementer. Dyrking av særinteresser, for eksempel fotball, har gjort dem til lesere, ofte initiert eller avhengig av fremstillinger av fenomenet i andre medier. Mer kunnskap om personen eller fenomenet er drivkraften, og lesingen av utvalgte bøker vil kunne supplere og utdype eksisterende kunnskaper, for eksempel om en kjent person eller et bestemt reisemål. Noen beskriver en spesiell interesse for dokumentariske fremstillinger av fenomener som kreftsykdom, narkomani eller nær døden-opplevelser:

Men da jeg gikk i 7-klasse på barneskolen og storesøsteren min gikk i 9-ende klasse forandret synet mitt seg på bøker. Hun hadde nemlig hørt om en bok, som læreren hennes hadde anbefalt. "Idas dans” av Gunnhild Corwin. Dette ble en bok som jeg leste flere ganger og ble veldig glad $i$.

Studenter som forteller om denne typen lesing forlanger ikke å bli oppslukt av boka gjennom spenning eller drama. De er allerede oppslukt av fenomenet boka handler om. En slik særinteresse blir som oftest ikke beskrevet å medføre økt interesse for skjønnlitteratur i sin alminnelighet. Sjangeren er mer journalistisk enn skjønnlitterær, noen ganger basert på eller supplert med filmatiske fremstillinger av den samme historien.

Identifikasjon, å relatere seg til andre gjennom å lese om noe virkelighetsnært, blir nevnt som motiverende faktorer av 16 studenter, men først og fremst blir en attraktiv leseopplevelse ofte knyttet til å bli "fanget inn i en annen verden”. En student beskriver for eksempel lesing av fantasy som å bli tatt med inn i en fremmed verden der hun kan "drømme seg bort" og "nyte hvert millisekund”. For å få lest boka er mange avhengige av at denne opplevelsen er så sterk at det er umulig “å legge boka fra seg”. Krim blir foretrukket fordi studentene opplever at spenning kan ha en slik effekt. Når det gjelder kjærlighetsdramaet er det en student som understreker at det trengs et "skikkelig drama” for å holde lesingen hennes i gang. I vampyrsjangeren, som mange av studentene setter pris på, blir kjærligheten for eksempel "dramatisert" ved at den blir knyttet til vold, grusomhet og død. Referansene til titler, som peker ut fantasy og krim som de mest populære sjangerne, samsvarer med disse beskrivelsene. Samlet blir det å drømme seg bort, forsvinne fra hverdagen, bli oppslukt eller bergtatt, nevnt som grunner til å lese av 16 studenter. Dette kravet til litteraturen er dermed blant dem som blir nevnt hyppigst. En student forteller at hvis "jeg ikke klarer å legge boka fra meg” så “mister jeg motivasjonen for å lese”. En annen skriver at "En bok må fenge meg fra første stund for at jeg skal gi den en sjanse. Som en utålmodig sjel har jeg ikke tid til å vente for lenge med å bli glad i boken”.

13 studenter forteller at lesing er en måte å stresse ned på, og enkelte beskriver dette som en form for meditasjon. 


\section{Hvorfor studentene synes at de burde lese}

Studentene vurderer først og fremst litteraturen i et nytteperspektiv. De som beskriver seg som lesere anser ofte at de er i en privilegert posisjon: "Jeg er veldig glad i å lese, og veldig takknemlig for det.” De har opplevd at lesingen har styrket språket deres, og "språk er nøkkelen til mange gleder her i livet”. Lesing anses som "god trening for hodet" og som inngangsporten til en hel rekke ferdigheter. På samme måten som i skolens læreplaner blir lesing forbundet med generell læreevne og skolemestring:

Grunnlaget foreldrene mine gav meg gjennom høytlesing har ført til at jeg har fått mye “gratis” på skolen. Jeg kan lese gjennom mye pensum på kort tid, og har aldri hatt lese- eller skrivevansker som har hindret meg i å gjøre det godt på skolen.

Denne vurderingen blir også delt av studenter som ikke har lyktes med å bli lesere:

Det gikk opp for meg at for å forbedre meg på skolen og få et bedre ordforråd måtte jeg lese mer, og kunne likeså godt lese romaner, krim og fantasy for å få dette til. En ting var å reflektere rundt det, en annen var å utføre. Jeg dro mange ganger til Deichmanske bibliotek og lånte bøker, men klarte aldri å fullføre en bok.

Noen av dem som ikke leser eller leser svært lite, forteller også at de enten gjerne skulle vært lesere, eller gjerne skulle lest mer av rent følelsesmessige årsaker. Noen begrunner dette med den positive leseopplevelsen de hadde som barn: "Det er en egen liten koselig tid hvor man setter seg sammen og finner en bok og kan bla, se på bilder, lese fortellinger eller bare dikte opp rundt bildene.” Andre har en positiv forestilling om lesehandlingen i sin alminnelighet: “[...] jeg synes det virker så koselig å kunne sette seg ned å lese en god bok.”

Flerkulturelle studenter beskriver, i større grad enn etnisk norske, kulturelle og språklige hindre i forhold til lesing av skjønnlitteratur:

Hjemme hadde ikke foreldrene mine innarbeidet seg lesekulturen, likevel hadde vi en liten samling av barnebøker i hus. Jeg ble ikke lest til så mye som jeg burde ha blitt, men litt var det.

Noen forteller likevel at de har klart å bli en leser. Det vanligste blant de som ikke leser, er imidlertid å beskrive det å bli en leser som et ønske eller håp for fremtiden.

Fremover vil jeg gjerne bli flinkere til å sette av tid til å lese bøker slik at jeg kan bli en engasjerende lærer som fremmer mine fremtidige elevers leselyst.

De studentene som relaterer lesing av litteratur til sin fremtidige lærergjerning, ser for seg en positiv sammenheng. 


\section{"Deviant cases"}

Det avvikende, "the deviant case", kan fortelle oss noe om et fenomen som vi går glipp av dersom vi bare fokuserer på det typiske eller gjennomsnittlige. Slike tilfeller får oss til å stille spørsmål som enten kan styrke eller svekke våre generelle antakelser (Roller \& Lavrakas, 2015). I vårt materiale er det to lesehistorier der engasjementet i litteratur får en type begrunnelse som samsvarer med tradisjonell dannelse. Også her blir behovet for spenning og for å drømme seg bort nevnt som drivkrefter, men flere andre blir samtidig utpekt. I den ene historien setter studenten pris på forfattere som Kafka, Homer, Hemingway, Hamsun, Shakespeare og Dickens fordi:

[...] det gir meg veldig mye tilbake både tankemessig og språkmessig. Jeg leser ofte mange bøker samtidig [...] noen leser jeg for historiens skyld, mens andre liker [jeg] å lese for språkbruken og måten bøkene får deg til å tenke på.

I den andre avvikende lesehistorien skriver studenten at "det som er fint med slike bøker [seilehistorier] er at man lagrer seg erfaring som man kan ta med seg når man selv skal ut i verden." Studenten "tror [...] at det er en bra ting, å lese mye som barn (og voksen). Fordi det gir deg mulighet til å reflektere over deg selv og livet, på en annen måte enn hvis du ikke hadde noe å referere til."”

I begge disse tilfellene blir et ønske om forståelse, kunnskap, både av seg selv og av den verdenen man befinner seg i, en drivkraft for å lese litteratur. Litteraturen blir slik sett en inngang til tradisjonell dannelse, ikke bare en flukt inn i en annen verden.

En litterær interesse som er stimulert av noe annet, eller mer enn å drømme seg bort, finner vi også hos en tredje student som begrunner en interesse for Poe og Wilde med at:

[...] de skriver på en vakker måte som skiller seg ut fra dagens litteratur (kanskje ikke så rart, siden de levde på 1800-tallet). Noe av det de har skrevet består mer av skildringer av følelser enn handlinger og objekter, dette åpner opp for mange forskjellige tolkninger.

Dette er ikke en like klar beskrivelse av egen lesing som del av en dannelsesprosess, men den peker utover spenning og virkelighetsflukt som motivasjon for å lese litteratur.

\section{Diskusjon}

I vår analyse av studentenes lesehistorier har vi ønsket å finne ut hvordan fenomenet lesing fremstår eller "presenterer seg for dem”. I fortolkningen av historiene rettet vi oppmerksomheten mot våre egne, og samtidig det vi har identifisert som studentenes, fordommer i møte med dette spørsmålet. 
Studentenes forklaringer på skjønnlitteraturen plass og betydning i livene deres kan deles i to. En del kan knyttes til deres rolle som unge voksne, altså til livsverdenen utenfor lærerutdanningen, og den andre delen kan knyttes til deres rolle som lærerstudenter i en utdanningsinstitusjon der vi selv er lærere. Den delen av studentenes livsverden som vi deler med dem i utdanningsinstitusjonen, har vi mulighet til å påvirke direkte. Den andre delen, som tilhører deres liv utenfor, kan vi bare påvirke indirekte. Uansett trenger vi kunnskap om den siste delen for å kunne gjøre gode valg i den første.

Studentene leverte inn sine lesehistorier etter at faglærerne deres gjennom flere uker hadde fortalt dem at barns lesing av skjønnlitteratur er viktig og verdifullt. Det vil si at de forteller lesehistoriene både som informanter og representanter (Kvale, 2005). De informerer om lesingen sin, men samtidig representerer de seg selv som lærerstudenter. De beskjedne referansene som studentene oppgav i fortellingene om seg selv, indikerte et motsetningsforhold mellom de leserne vi som litteraturlærere hadde oppfordret dem til å være, og den faktiske opplevelsen de hadde av sin egen lesing. I denne situasjonen hadde ikke studentene mange gode grunner for å underrapportere. Det er mer rimelig å anta at de i størst mulig grad ønsket å fremstå som ivrige lesere. Forholdet til litteratur som kommer til uttrykk i historiene deres kan peke i den retningen. En uttalt manglende leseinteresse blir ikke forklart med en negativ vurdering av litteraturen som kulturuttrykk. Selv om det er mange som ikke klarer å få noe ut av å lese litteratur, er det ingen som fremmer et negativt syn på litteratur, eller stiller spørsmål ved litteraturens rolle i skolen. Studentene presenterer seg selv, ikke litteraturen, som problemet, og svært mange beklager at de ikke leser mer.

Studentenes opplevelse av lesning som fenomen i egne liv har vi beskrevet på bakgrunn av de generelle tendensene i materialet. Det betyr at individuelle beskrivelser og forklaringer har kommet i bakgrunnen, mens typiske trekk ved studentenes opplevelse av lesingen gjennom livsløpet har blitt trukket frem. De tendensene vi finner i de store tallene fra annen forskning (Vaage, 2015; DNF, 2015; NOVA, 2015), nemlig at skjønnlitterær lesing er nedadgående blant unge mennesker i dag, blir bekreftet når vi ser på materialet på denne måten.

Vår analyse gir anledning til å gå videre fra beskrivelser av hva studentene leser til hvordan de samlet sett forklarer sitt forhold til å lese skjønnlitteratur. Dermed kan våre funn gi forklaringer på de typiske tendensene som er påvist i den eksisterende forskningen på grunnskolelæreres lesing som vi refererer til i starten av artikkelen.

Det første spørsmålet vi stilte i innledningen var hva studentene har lest. Studentene nevner få titler og forfatternavn i historiene sine. Barnelitteraturen dominerer. Når det gjelder voksenlitteraturen er krim og fantasy de dominerende sjangerne. Tallenes troverdighet styrkes når svaret på dette første spørsmålet ses i sammenheng med svarene vi fant på det andre spørsmålet vi stilte, nemlig hvordan studentenes lesing hadde utviklet seg gjennom livsløpet. Selv om 2/3 av studentene opplyser at de alltid har likt å lese, så forteller denne gruppen samlet 
sett at lesingen deres har avtatt med årene. Ganske mange formulerer seg på en måte som tyder på at de i dag leser lite eller ingenting. Den siste tredelen består av studenter som enten har mistet interessen for å lese, eller aldri har vært interessert. 16 studenter som opprinnelig ikke har lest, men så har utviklet seg til å bli lesere, inngår også i denne gruppen. Undersøkelsen bekrefter dermed samlet sett den spesielt svake leseinteressen blant grunnskolelærere som er påvist av Petterson (2009) og Wiklund et al. (2016).

Wicklund et al. (2016) er basert på samme type materiale som vår undersøkelse. De relaterer sine funn til begrepet litterær kompetanse, slik dette begrepet blir definert av henholdsvis Appleyard (1990), Steffensen (1995) og Torell et al. (2002). Det studentene faktisk har lest blir et argument for hvilken kompetanse de har opparbeidet: "lesehistoriene, nettopp ved at de viser individuelle erfaringer, gir et godt bilde av hvilke sider av litterær kompetanse studentene er fortrolige med" (Wicklund et al., 2016, s. 129). Med spesiell henvisning til Hennig (2010) finner Wicklund et al. på dette grunnlaget "få spor av tolkende og reflekterende lesing" (s.129). Samtidig fremholder de at det er vanskelig å trekke slutninger fra hva studentene har lest til hvilken kompetanse de har opparbeidet gjennom lesingen.

Kanskje spørsmålet om litterær kompetanse kan bli sikrere besvart med et materiale av den typen for eksempel Kjelen (2014) eller (Skaftun et al., 2015) har analysert. Svaret vårt materiale gir på det tredje spørsmålet vi stilte, nemlig hvordan studentene forklarer sitt forhold til å lese skjønnlitteratur, gir først og fremst mer kunnskap om hvilket grunnlag studentene selv har for å skape interesse for litteratur i klasserommet.

\section{Grunner til å lese}

Det er gjennomgående at studentene forestiller seg både mer kunnskaper, mer dyptgående innsikter og større språkforståelse dersom de leser mer, og de sier at de ønsker å lese mer. Samtidig blir ikke litterær kvalitet tematisert tilknyttet dette. Når det blir pekt på at lesingen kan tilføre spesifikke kunnskaper, er referansene mest typisk dokumentarlitteratur der et litterært grep er tatt i bruk for å skildre virkelige fenomener, personer eller hendelser. En fotballspillers beretning om sitt liv, ført i pennen av en journalist, kan gi leseren mer kunnskap om sitt idol, samtidig som bidraget til utviklingen av leserens språk og refleksjon ofte vil være begrenset av en utpreget prosaisk, og dermed lettlest, fremstillingsform.

Bare i et par, tre tilfeller, som vi ovenfor har kalt 'deviant cases', blir lesingen knyttet til et ønske om mer dyptgående inngang til språk-, identitets- og kunnskapsutvikling. Det finnes altså en splittelse i vårt materiale mellom studentens faktiske lesing, og deres forestillinger om hva denne lesingen kan tilføre dem. Dette gjenspeiler kanskje at lesing av bøker fremdeles har en tendens til å bli oppvurdert på en udifferensiert måte i vår kultur. Det er mulig at enhver form for lesing medvirker til større leseferdighet, men når utviklingen av 
språkforståelse og refleksjon blir knyttet til skjønnlitteratur skyldes det at språket og fremstillingen yter en form for motstand i forhold leserens forforståelse. Lesingen krever et merkbart kognitivt arbeid for å oppnå forståelse. Studentene leser stort sett ikke denne typen skjønnlitteratur. Bøkene de foretrekker tilfredsstiller først og fremst et behov for spenning og flukt. Det utelukker ikke at bøkene har andre litterære kvaliteter, men ønsket om å bli oppslukt av spenning innebærer for mange av studentene å velge bøker som i liten grad yter den motstanden som verdien av å lese skjønnlitteratur mest typisk blir knyttet til i læreplaner og politiske dokumenter.

\section{Grunner til ikke å lese}

Lærerstudentene i Kennedys undersøkelse (2014) fremholdt mangel på tid som den fremste årsaken til ikke å lese utenom studiene. Det gjelder også de studentene som i vår undersøkelse opplyser at de alltid har likt å lese, men ikke lenger får lest så mye de skulle ønske. Noen forteller at de i hverdagen heller velger andre medier fordi de opplever bruken av dem som mindre krevende. For noen har det, på tross av et positivt forhold til lesing, blitt et problem å finne bøker som interesserer dem nok. Blant de som ikke lenger liker å lese, forteller noen om lese- og skriveproblemer, andre om en flerkulturell bakgrunn som har gjort lesing vanskelig for dem. Konsentrasjonsproblemer blir også nevnt, sammen med mangel på tid og anledning. En mindre gruppe har aldri vært interessert i å lese.

De studentene som faktisk er lesere vil helst oppleve fantasy, spenning eller intenst drama. De leser for å glemme hverdagen, kose seg og slappe av. Mange av dem synes også det er vanskelig å finne tid til å lese, og for å gjennomføre lesingen er mange avhengige av at boka er så spennende at den blir umulig å legge fra seg. Hvis ikke gir de opp etter noen få sider. For å komme frem til et slikt "point of no return" er det mange ting som må klaffe. Tid er den forutsetningen disse studentene nevner oftest. Noen mener de bare har tilstrekkelig med tid i feriene sine. Det betyr at lesingen blir svært begrenset. Det taler mot et mer positivt forhold til lesing i fremtiden hos disse studentene at lesingen allerede har blitt valgt bort i en livssituasjon der de fleste kanskje har mer tid til disposisjon, enn de høyst sannsynlig vil få senere i livet. Det svekker også en slik forventning at mange studenter bare kan lese når de opplever uforstyrret fred og ro, uten anledning til å velge alternativer som "frister mer". Studentene stiller høye krav til spenning, og forutsetter å bli revet med av det de leser på en måte som får dem til å glemme tid og sted. Hvordan er det egentlig mulig at andre ting ikke skal "friste mer" med slike krav til litteraturen? Andre medier imøtekommer denne typen spenningsbehov minst like effektivt, samtidig som de kognitive anstrengelsene ved lesingen blir overflødige. Skjønnlitteratur har stadig vanskeligere for å konkurrere med film og digitale medier på disse premissene. 


\section{Litteraturens fremtid i skolen}

Ut fra vårt materiale finner vi altså at bare 3 av 163 studenter oppsøker litteratur for å finne ut hvem de selv er, i samsvar med dannelsestenkingen som før LK06 gav skjønnlitteraturen en privilegert plass på norske læreplaner. Når flertallet av studentene i vårt materiale beskriver sin egen lesing, er drivkraften et ønske om faktakunnskap, spenning og å kunne drømme seg bort fra hverdagen. Det er de faktiske grunnene til at de leser, og mange leser ikke på dette grunnlaget heller. Selv om studentene faktisk har erfart at litteratur kan avhjelpe kjedsomhet og tilfredsstille behov for drøm og spenning, velger de bort lesingen. De har prøvd, men litteraturen har ikke kunnet holde dem fast. Boken ble kjedelig og de orket ikke lese mer etter noen sider. En rimelig antakelse er derfor at de som forteller at de ikke er lesere, heller ikke vil bli det, ettersom ønsket om å bli leser hovedsakelig ser ut til å drives av en instrumentell nyttetenkning.

En slik tendens har også blitt fremholdt i annen forskning (Sullivan \& Brown, 2013).

En læreplanutvikling der litterære titler har blitt erstattet med målbare ferdighetsmål utformet i kulepunkter kan ha bidratt til å bygge opp under denne nyttetenkningen (Løvland, 2010, s. 52-53). Tendensen til at målbare ferdigheter overskygger den mer kontekstuelt formulerte dannelsestenkingen er også i høy grad til stede i dagens lærerutdanning (se f.eks. Ongstad, 2014, s. 187-188).

Verdien av å ha blitt lest for blir også instrumentelt begrunnet. Lesingen i barndommen er et kjært minne, men har ikke gjort dem til lesere. De gode leseropplevelser er ikke først og fremst knyttet til litterær kvalitet, men til mellommenneskelige relasjoner. Lesing er faktisk nødvendig for å lære å lese og skrive, og dermed blir all lesing i småskolealder ansett som verdifull. Senere har man lært å lese, og da er ikke skjønnlitteraturen like viktig lenger. Som voksne klarer svært mange av studentene i denne undersøkelsen rett og slett ikke å lese lenger, selv om mange håper på et slags mirakel en gang i fremtiden som skal gjøre dem til lesere likevel. De synes ofte selv at de burde lese mer, men de er ikke villige til å ofre tiden og anstrengelsene det krever. Noen forteller at de i tillegg mangler konsentrasjonsevne, andre har lese- og skriveproblemer.

Flere fremholder tvangen knyttet til lesing i skolen som noe som har kverket både leselysten og lesingen deres. Det kan tyde på at mer institusjonell tilrettelegging for studentenes egen lesing ikke vil kunne forandre på at de velger bort litteraturen.

I en vurdering av hva studentenes forhold til litteratur vil bety for deres arbeid som lærere, kan det være grunn til å skille mellom tidlige og senere leseerfaringer. Praktisk talt alle har satt pris på å ha blitt lest for som barn. Denne leseopplevelsen, mest typisk på mammas eller pappas fang før skolealder, er nært forbundet med en omsorg og nærhet som ingen nedvurderer. Foreldre som har forsømt seg blir unnskyldt. De som har opplevd å bli lest for er takknemlige. Det er senere problemene oppstår. Da blir man ikke lenger lest for, men må lese selv. Dessuten er ikke lesingen basert på en sterk følelsesmessig 
binding, men på det mange opplever som tvang. Selv om det også går an å velge bøker selv, både i og utenfor skolen, fremstår andre former for mediebruk som mer attraktive. Dermed opplever veldig mange at det er vanskelig å opprettholde lesingen av skjønnlitteratur som ungdom og voksne.

Hva vil disse motstridende erfaringene bety når disse studentene blir lærere i småskolen? Kan leseopplevelsen på mors eller fars fang kompensere for leseinteressen som er tapt hos den voksne læreren når det gjelder å formidle litteratur i klasserommet?

Lærerstudentenes egne historier viser at for mange har positive leseopplevelser som barn, ikke vært nok til at de selv har blitt lesere som voksne. For å skape leseinteresse hos elevene må læreren selv være en leser (Ulland, Palm \& Andreassen, 2014, s. 120). I så fall er det et problem at så lite tyder på at disse studentene vil komme til å lese mer i fremtiden.

På tross av de positive barndomsopplevelsene mangler studentene den interessen for litteratur som ifølge Ulland et al. (2014) er nødvendig for å være en "leseoppdrager" med "kultur for lesing". Hvis de har rett, er det rimelig å anta at disse lærerstudentenes frafall som lesere betyr at lesing av skjønnlitteratur stadig vil fortsette å tape terreng i skolen, også på de tidligste trinnene.

Konklusjonen må bli at ivaretakelsen av litteraturen i skolen bare i begrenset grad kan være basert på lærernes eget forhold til lesing. Lærerutdanningene bør verken forutsette at studentene allerede er lesere, eller at de på egenhånd vil utvikle seg til å bli det senere i livet.

\section{Referanser}

Alexander, P.A. (2005). The path to competence: A lifespan developmental perspective on reading. Journal of Literacy Research, 37(4), 413-436.

Andersen, P. L. og Bakken (2015) Ung i Oslo 2015. NOVA Rapport 8/15. Oslo: NOVA.

Applegate, A.J., og Applegate, M.D. (2004). The Peter effect: Reading habits and attitudes of preservice teachers. The Reading Teacher, 57 (6), 554-563.

Appleyard, A. J. (1990). Becoming a reader. The Experience of Fiction from Childhood to Adulthood. New York: Cambridge University Press.

Arfwedson, G.B. (2006). Litteraturdidaktik från gymnasium til förskola. En analys av litteraturundervisningens hur-fråga med utgångspunkt från svenska didaktiska undersøkningar i ett internationellt perspektiv. Stockholm: Vetenskapsrådets rapportserie 11.2006.

Bergersen, V. (2015). Kan du lese for meg? En studie av elevers leserelaterte ferdigheter ved skolestart sett i sammenheng med lesemiljø i hjemmet. Masteroppgave, Institutt for grunnskolelcererutdanning, idrett og spesialpedagogikk, Universitetet i Stavanger.

Brink, L. (2009). Skönlitteraturens väg til klassrummet. Läsarkarriär, skolkanon och verklighetsanpassning hos lärare i grundskolan. I L. Kåreland (red.). Läsa bör man ... ?den skönlitterära texten i skola och lärarutbildning (s. 38-65). Stockholm: Liber.

Clark, C \& Picton, I. (2012). Family Matters: The Importance of Family Support for Young People's Reading. Findings from the National Literacy Trust's annual survey 2011. London: National Literacy Trust. 
Den Norske Forleggerforening. (2014). Leserundersøkelsen 2014. Hentet fra http://www.forleggerforeningen.no/filemanager/download_file/file/719890.pdf/Leserunde rsøkelsen\%202014.pdf

Dokset, K.M. (2015). Den litterære tekst som estetisk læremiddel - Om Thomas Illum Hansens Kognitiv litteraturdidaktikk. Norsklæraren, 4, 22-28.

Finlay, L. (2012). Debating phenomenological research methods. I N. Frieesen, C. Henriksson and T. Saevi (red.) Hermeneutic phenomenology in education - Method and Practice. Rotterdam: Sense Publishers.

Gadamer, H.G. (1975/1996). Truth and method (Second revised edition). London: Sheed and Ward.

Hamre, P. (2014). Norskfaget og skjønnlitteraturen. Ein studie av norskfaglege normtekstar 1739-2013. UIB: Bergen (PhD-Thesis)

Husserl, E. (1983). Ideas pertaining to a pure phenomenology and to a phenomenological philosophy. First book (F. Kersten, overs.) The Hague: Martinus Nijhoff. (original utgave publisert 1913).

Johnsson, U.J. S. \& Jönsson, A. (2006). Book Reading in Leisure Time: Long-Term Changes in Young Peoples’ Book Reading Habits. Scandinavian Journal of Educational Research, 50(5), 519-514.

Jönsson, A. \& Eriksson, B. (2003). Lärarstuderandes läsvanor - hur mycket och vad läser blivande lärare? Rapporter om utbildning 2003:4.

Kaspersen, P. ( 2012). Litteraturdidaktiske dilemmaer og løsninger. En undersøgelse af litteraturdidaktikkens aktuelle status i Norden. I S. Ongstad (red.) Nordisk morsmålsdidaktikk - Forskning, felt og fag (s. 47-73). Oslo: Novus Forlag.

Kennedy, A. S. (2014). Reading Habits and Attitudes of Pre-Service Teachers: A Case Study. Ed.D. Dissertation, Widener University.

Kjelen, H. (2013). Litteraturundervisning i ungdomsskulen. Kanon, danning og kompetanse. Trondheim: NTNU (PhD-thesis).

Kjelen, H. (2014). Litterær kompetanse hos nye lærarstudentar. Norsklæraren, 2, 56-66.

Kvale, S. (2005). Om tolkning af kvalitative forskningsinterviews. Nordisk Pedagogik, Vol. 25, 3-15.

Langdridge, D. (2008). Phenomenology and critical psychology: Directions and debates in theory and research. Social and Personality Psychology Compass, 2, 1126-1142.

Løvland, A. (2010). På jakt etter svar og forståing. Bergen: Fagbokforlaget.

Martinsson, B.-G. (2012). Litteraturundervisning som motståndets didaktik? Om förhållandet universitetsämne, ämnesdidaktik och skolämne. I S. Ongstad (red.) Nordisk morsmålsdidaktikk - Forskning, felt og fag (s. 47-73). Oslo: Novus Forlag.

McKool, S.S., \& Gespass, S. (2009). Does Johnny's reading teacher love to read? How teachers' personal reading habits affect instructional practices. Literacy Research and Instruction, 48, 265 - 276. doi: 10.1080/19388070802443700

Nathanson, S., Pruslow, J., \& Levitt, R. (2008). The reading habits and literacy attitudes of inservice and prospective teachers: Results of a questionnaire survey. Journal of Teacher Education, 59(4), 313-321.

Nicolaysen, B.K. \& Aase, L. (red.) (2005). Kulturmøte i tekstar: Litteraturdidaktiske perspektiv. Oslo: Det Norske Samlaget.

NOVA (2015). Ungdata. Nasjonale resultater 2014. NOVA Rapport 7/15. Oslo: NOVA.

Ongstad, S. (2014). Om faglighet og språklighet i Nasjonalt kvalifikasjonsrammeverk (NKR) i lys av generell læreplan for grunnutdanning (1-13). I B. Kleve, S. Penne \& H. Skaar (red.), Literacy og fagdidaktikk i skole og lcererutdanning. Oslo: Novus. 
Penne, S. (2012). Hva trenger vi egentlig litteraturen til? I N. Elf og P. Kaspersen, Den nordiske skolen - finnes den? Didaktiske diskurser og dilemmaer i skandinaviske morsmålsfag. Oslo: Novus.

Petersson, M. (2009). “Jag kan inte komma på nåt jag läst på gymnasiet, det måste ju betyda nåt eller hur? - om blivande svensklärare som läsare”. I L. Kåreland (red.). Läsa bør man...? -den skönlitterära texten I skola och lärarutbildning (s. 16-37). Stockholm:Liber.

Roller, M.R. \& Lavrakas, P.J. (2015). Applied qualitative research design: A total quality framework approach. New York: The Guilford Press.

Scholes, R. (1998). The rise and fall of English: Reconstructing English as a discipline. New Haven: Yale University Press.

Scholes, R. (2011). English after the fall: from literature to textuality. Iowa City: University of Iowa Press.

Schwandt, T.A. (2015). The SAGE Dictionary of Qualitative Inquiry (4.utg.) London:Sage

Skaftun, A., Karlsen, O. \& Syvertsen, E.M. (2015). Litteratur og læring - om faglighet for framtiden. Norsklceraren, 4, 15-21.

Storrusten, K. H. (2010). Men hva leser lcererne? Masteroppgave, Universitetet i Oslo.

Steffensen, B. (1995). Når børn læeser fiktion: grundlaget for den nye litteraturpæedagogik. København: Akademisk forlag.

Sullivan, A. \& Brown, M. (2013). Social inequalities in cognitive scores at age 16: The role of reading. CLS Working Paper 2013/10. Institute of Education, University of London.

Thorson, S. (2009). Blivande svensklärare om att “läsa” och “förstå” skönlitteratur. I L. Kåreland (red.). Läsa bör man ...?-- den skönlitterära texten i skola och lärarutbildning (s.86 - 113). Stockholm: Liber.

Ulland, G., Palm, K. \& Andreassen, R. (2014). Den andre lese- og skriveopplæringa: lesing. I B. K. Jansson \& H. Traavik (red.), Norskboka 2. Norsk for grunnskolelcererutdaning 1-7. Oslo: Universitetsforlaget.

Torell, Ö., Bonsdorff, M., Bäckmann, S. \& Gontjarova, O. (2002). Hur gör man en litteraturläsare. Om skolans litteraturundervisning i Sverige, Ryssland och Finland. Härnösand: Mitthögskolan.

Vaage, O. F. (2015). Norsk mediebarometer 2014, Statistiske analyser 143, Statistisk sentralbyrå.

Wicklund, B., Larsen, A.S. \& Vikbrant, G. (2016). Lærerstudenten som leser - en undersøkelse av litterære erfaringer hos en gruppe norske og svenske lærerstudenter. Nordisk tidsskrift for pedagogikk og kritikk, 2(1), 119-132. 


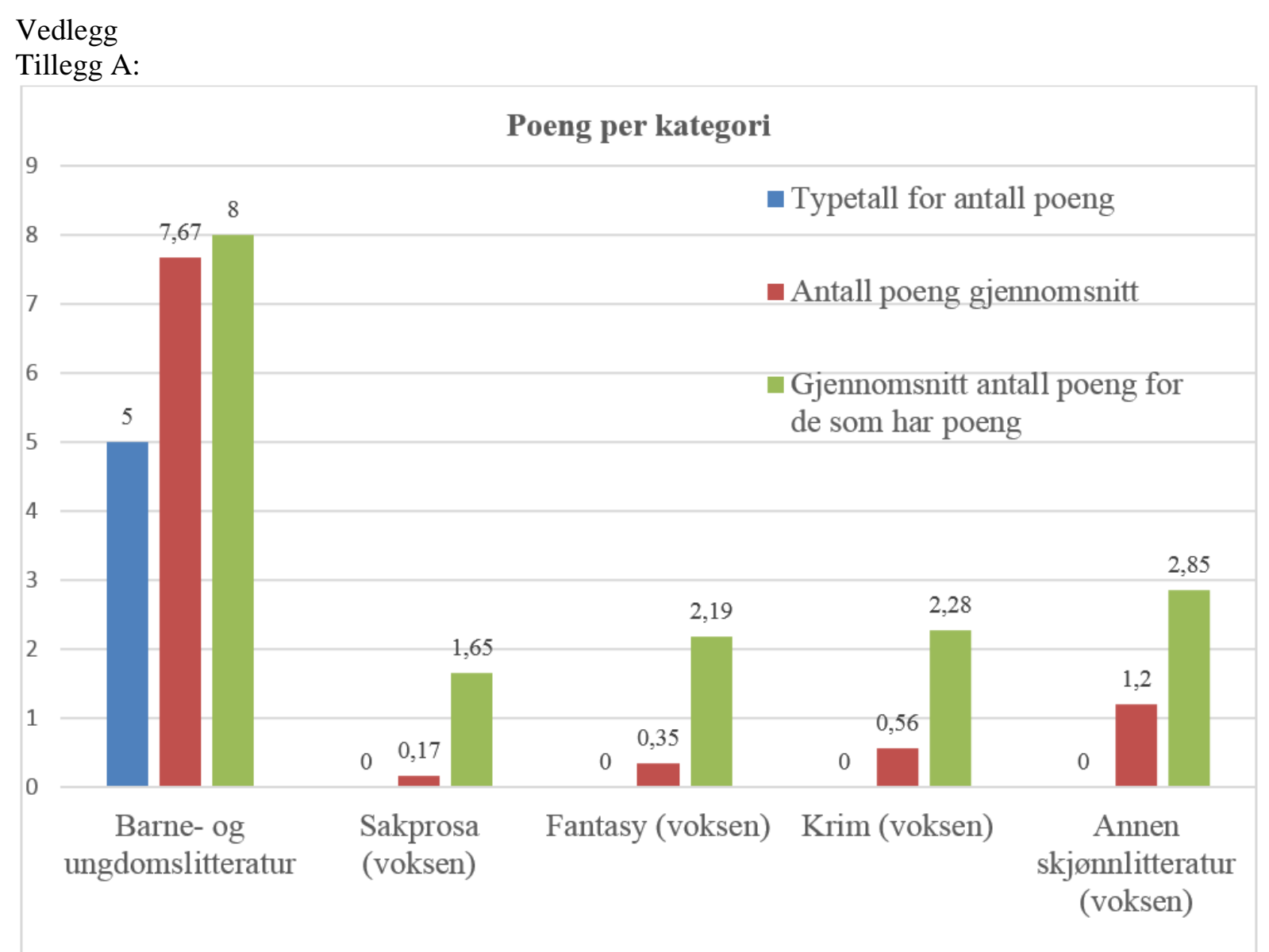


Tillegg B: Fordeling av titler og forfatternavn som er nevnt i studentenes historier

\begin{tabular}{|c|c|c|c|c|c|c|}
\hline & $\begin{array}{l}\text { Barne- og } \\
\text { ungdoms- } \\
\text { litteratur } \\
\end{array}$ & $\begin{array}{l}\text { Sakprosa } \\
\text { (voksen) }\end{array}$ & $\begin{array}{l}\text { Fantasy } \\
\text { (voksen) }\end{array}$ & \begin{tabular}{|l}
$\begin{array}{l}\text { Krim } \\
\text { (voksen) }\end{array}$ \\
\end{tabular} & \begin{tabular}{|l} 
Annen \\
skjønn- \\
litteratur \\
(voksen) \\
\end{tabular} & Totalt \\
\hline Antall poeng & 1250 & 28 & 59 & 91 & 202 & 1630 \\
\hline \begin{tabular}{|l} 
Prosentvis \\
fordeling av \\
poengene
\end{tabular} & $77 \%$ & $2 \%$ & $4 \%$ & $5 \%$ & $12 \%$ & $100 \%$ \\
\hline $\begin{array}{l}\text { Typetall for } \\
\text { antall poeng }\end{array}$ & 5 & 0 & 0 & 0 & 0 & 6 \\
\hline $\begin{array}{l}\text { Antall poeng } \\
\text { gjennomsnitt }\end{array}$ & 7,67 & 0,17 & 0,35 & 0,56 & 1,2 & 10 \\
\hline \begin{tabular}{|l} 
Prosent \\
studenter uten \\
poeng
\end{tabular} & $4 \%$ & $90 \%$ & $83 \%$ & $75 \%$ & $56 \%$ & $2 \%$ \\
\hline $\begin{array}{l}\text { Gjennomsnitt } \\
\text { antall poeng } \\
\text { for de som har } \\
\text { poeng }\end{array}$ & 8 & 1,65 & 2,19 & 2,28 & 2,85 & 10,25 \\
\hline \begin{tabular}{|l} 
Prosent \\
studenter med \\
poeng som \\
bare har 1 \\
eller 2 poeng
\end{tabular} & $10 \%$ & $76 \%$ & $78 \%$ & $78 \%$ & $52 \%$ & $8 \%$ \\
\hline \begin{tabular}{|l} 
Prosent \\
studenter som \\
bare har 1 \\
eller 2 poeng \\
\end{tabular} & $10 \%$ & $8 \%$ & $13 \%$ & $19 \%$ & $23 \%$ & $7 \%$ \\
\hline $\begin{array}{ll}\text { Prosent } & \\
\text { studenter med } \\
\text { mer enn } 2 \\
\text { poeng }\end{array}$ & $86 \%$ & $2 \%$ & $4 \%$ & $6 \%$ & $21 \%$ & $90 \%$ \\
\hline
\end{tabular}


Tillegg C: Forhold til lesing i ulike faser av livet: barn, ungdom og voksen. Markert med P (positiv), N (negativ) eller U (umarkert)

\begin{tabular}{|c|c|c|c|}
\hline & $\begin{array}{ll}\text { Barn } & - \\
\text { ungdom } & - \\
\text { voksen } & \end{array}$ & $\begin{array}{l}\text { Antall } \\
\text { studenter }\end{array}$ & $\begin{array}{l}\text { Antall } \\
\text { studenter } \\
\text { fordelt på } \\
\text { hver gruppe }\end{array}$ \\
\hline \multirow[b]{4}{*}{ Liker ikke å lese } & NNN & 10 & \multirow[b]{4}{*}{18} \\
\hline & NNU & 3 & \\
\hline & NUN & 1 & \\
\hline & UUU & 4 & \\
\hline \multirow{5}{*}{$\begin{array}{l}\text { Liker ikke å lese } \\
\text { (men likte det } \\
\text { før) }\end{array}$} & PNN & 10 & \multirow[b]{5}{*}{31} \\
\hline & PNU & 5 & \\
\hline & PPN & 5 & \\
\hline & PUN & 3 & \\
\hline & PUU & 8 & \\
\hline \multirow{3}{*}{$\begin{array}{l}\text { Liker å lese } \\
\text { (men ikke før) }\end{array}$} & NNP & 5 & \multirow[b]{3}{*}{11} \\
\hline & NPP & 5 & \\
\hline & UUP & 1 & \\
\hline \multirow[b]{2}{*}{ Liker å lese } & PNP & 14 & \multirow[b]{2}{*}{103} \\
\hline & PPP & 89 & \\
\hline
\end{tabular}

